\title{
Study of phenotypes variability of pollen grains Malus domestica Borkh. by scanning electron microscopy
}

\author{
Vladimíra Horčinová Sedláčková1*, Miloš Hulin${ }^{1}$, Radovan Ostrovský$^{2}$, Svetlana Motyleva ${ }^{3}$ \\ ${ }^{1}$ Slovak University of Agriculture in Nitra, Faculty of Agrobiology and Food Resources, \\ Institute of Plant and Environmental Sciences, Nitra, Slovakia \\ ${ }^{2}$ Slovak Academy of Sciences, Institute of Forest Ecology, Plant Pathology \& Mycology, Nitra, Slovakia \\ ${ }^{3}$ Federal State Budgetary Scientific Institution "All-Russian Horticultural Institute for Breeding, \\ Agrotechnology and Nursery“, Moscow, Russia \\ ORCID \\ Vladimíra Horčinová Sedláčková: https://orcid.org/0000-0002-5844-8938 \\ Radovan Ostrovský: https://orcid.org/0000-0003-2942-0933 \\ Svetlana Motyleva: https://orcid.org/0000-0003-3399-1958
}



Article Details:

Received: $\quad$ 2021-08-22

Accepted: $\quad$ 2021-09-07

Available online: 2021-11-30

DOI: https://doi.org/10.15414/ainhlq.2021.0029

\begin{abstract}
The studying of Malus domestica Borkh. pollen allows us to determine the details of morphological characteristics and describe the most important parameters and pollen sculpture that can be used to identify representatives of species. We analysed pollen morphology of seven Malus domestica genotypes from old and local varieties from the territory of Slovakia via a scanning electron microscope. We used principal components analysis to explore variability in pollen grain size (polar and equatorial diameter), shape, aperture type, and exine ornamentation. The complexity of these morphological characteristics and ultrastructure allows determining the differences or similarities between the same and various species and genotypes, which may be a useful tool for systematics with significant diagnostic value. Findings confirmed small differences among the genotypes in measured traits with polar and equatorial diameters in the range from 31.85 to $42.85 \mu \mathrm{m}$ and from 21.23 to $23.93 \mu \mathrm{m}$, respectively. Shape index (P/E ratio) depending on elongation or roundness of pollen grains varied from 1.44 to 1.87 . Hierarchical cluster analysis and principal component analysis of morphological data helped to compare evaluated morphometric parameters and identified five closely related groups. It was noted that diversity of surface sculpturing of pollen grains in combination with shape and size enables to use of a complex of thin morphologic signs for $M$. domestica pollen identifications. Pollen data combined with other morphological evidence (e.g., floral characters) have more recently become an important indicator of which genotypes may be the best representatives of species.
\end{abstract}

Keywords: Malus domestica, pollen, SEM, sculpture, morphology

\section{Introduction}

Pollen morphology has developed throughoutlong-term evolution and shows species-specific characteristics (Erdtman, 1969; Blackmore et al., 2007; Katifori et al.
2010. The complex morphological characteristics and ultrastructure of pollen grains allow determining the differences or similarities between the species of fruit trees.

\footnotetext{
*Corresponding Author: Vladimíra Horčinová Sedláčková, Slovak University of Agriculture in Nitra, Institute of Plant and Environmental Sciences, Slovakia

$\triangle$ vladimira.sedlackova@uniag.sk
} 
Quantitative (dimensions) and qualitative (ornamentation, colour) data of pollen have significant value in botanical (Smitha et al., 2018) and taxonomic classification, due to preserved palynological features in many plants (Dogan and Baysal, 2019).

The exine sculpturing, aperture and aperture zone structure, grain shape, and grain size are all useful characters to distinguish genera and even species of Rosaceous pollen (Hebda et al., 1988; Motyleva et al., 2017).

External variables such as extreme climatic changes, but also mineral nutrition and many internal factors (e. i. number of chromosomes) may contribute to the variability of pollen morphological features, especially pollen grain size (Benčat' et al., 1988; Ostrolucká and Križo, 1989). Fogle (1977a, b) used the length and width of the pollen grain, depth of exine ridges and prominence of pits in the exine to distinguish peach, nectarine, plum, cherry, apricot, apple and pear. Pollen ornamentation arrangement patterns are important to the exploration of plant genetic evolution and systematic taxonomy (Zhang et al. 2017; Elysiane et al. 2018). However, arrangement patterns are normally difficult to quantify (Zhang et al., 2017). Walker investigated pollen ornamentation characteristics in 1000 species from 35 families and found that pollen grain exine ornamentation evolution to exhibit an overall exhibit trend from regular to irregular and from simple to complicated (Walker, 1974). He and Hsu investigated the pollen morphology of 26 species and 5 hybrids of the genus Malus (He and Hsu, 1991). They pointed out that the major evolutionary trend of striae arrangement was from regular and parallel to irregular, dense and interlocking.

Previously, the pollen of some varieties of $M$. domestica Borkhausen was identified by some authors in America (Fogle, 1977a, b), New Zealand (Currie et al., 1997), Iran (Joneghani, 2008), Slovakia (Motyleva et al., 2017), Russia (Motyleva et al., 2018), Czech Republic (Pospiech et al., 2019).

The aim of the study was general characteristics and significant morphological traits of pollen grains of the domesticated apple (Malus domestica Borkh.) genotypes cultivated in Slovakia. We assumed that in the gene pool it is possible to detect the variability of quantitative and qualitative traits on the pollen grains and certain specific differences between the genotypes as intraspecific variability.

\section{Material and methodology \\ Pollen samples and localization}

Pollen samples of $M$. domestica (Md) were collected in the territory of Slovakia. As genetic resources were used old and local varieties from different areas of Slovakia which are kept ex situ in a clone repository in the village Bacúch (590-630 altitude, m. above s. l.). The whole territory of Slovakia belongs to the temperate climate zone. As the altitude rises, temperature decreases, precipitation increases, soil type changes, and the growing season is shorter.

Fresh flowers (not opened) were collected randomly from the different genotypes at the balloon stage (May 2011). Pollen samples released from dry flowers were further dried under laboratory conditions. The dry pollen was used for a microscopic study of morphological characteristics. The samples of pollen grains were applied to double-tape, fastened to metal object tables with a $10 \mathrm{~mm}$ diameter.

Analyses were studied at the All-Russian Horticultural Institute for Breeding, Agrotechnology and Nursery (Moscow, Russian Federation) using scanning and transmission electron microscopy. The morphometric parameters were carried out on 50 pollen grains from each genotype using the AxioVision Rel. 4.8.2.0. The length of the polar axis (P) and the equatorial diameter (E) of grains, P/E ratio were measured and compared among studied samples, the structure of pollen grain surface was described.

\section{Morphometric analysis}

The measurement of morphometric parameters was carried out on 50 pollen grains from each genotype using the AxioVision Rel. 4.8.2.0 program. The measurements were made in micrometres $(\mu \mathrm{m})$. The characterization of pollen grains was calculated by taking the following parameters: the polar axis ( $\mathrm{P}$ - the line connecting the proximal and distal pole), the equatorial axis ( $\mathrm{E}$ - the line perpendicular to the polar axis and located in the equatorial plane), proximal/equatorial ratio (P/E). The pollen grains were studied at the laboratory of the Institute of Biodiversity Conservation and Biosafety using an electron microscope Carl Zeiss LS 15. The description terminology has been established with regards to Fogle (1977a, b), Martens and Fretz (1980), Marcucci et al. (1984), He and Hsu (1991), Halbritter et al. (2018), Auer (2021). The comparative morphological study of the pollen grains was performed according to the working rules on the SEM JEOL JSM-6390 in the conditions of low vacuum $(\mathrm{P}=60 \mathrm{~Pa})$ with the following zooming: 500 times - during the measurements; 
2 500-10 000 times - while taking the pictures of the exine sculpture features. Using the regime of low vacuum allows the pollen to be studied without its preliminary chemical treatment and undistorted data to receive about the research object, which makes the process of the probe preparation easier. Typical exine patterns, shape, size, and dimensions of pollen grains for each $M$. domestica genotype were determined by using a scanning electron micrograph (SEM).

\section{Statistical analyses}

Basic statistical analyses - the minimal and maximal values of the traits, arithmetic means, and coefficient of variation (CV, \%) were performed using PAST 2.17. Results of the morphometric analysis were determined by mean \pm standard deviation (SD) and statistical significance was estimated. The level of variability was determined by Stehlíková (1998). Pearson's correlation coefficient was used to depict the relationship between the two traits. Hierarchical cluster analyses of similarity between phenotypes were computed by the Bray-Curtis similarity index and were performed using PAST 2.17. Principal component analysis (PCA) was performed to evaluate relationships among variables and some possible genotype groupings based on similar properties by using XLSTAT procedure (XLSTAT 7.5, Addinsoft, USA). All the observed traits were shown in graphic form.

\section{Results and discussion}

Research of morphological features of pollen grains from specific genotypes by scanning electron microscopy are important and useful for systematic botany and taxonomy, palaeobotany, phylogeny, and breeding programmes, e.g. Prunus spp. (Miaja et al., 2000; Arzani et al., 2005), Cornus mas L. (Mert, 2009), Diospyros spp. (Grygorieva et al., 2010, 2017), Corylus avellana L. (Nikolaieva et al., 2014), Castanea sativa Mill. (Grygorieva et al., 2015; Horčinová et al., 2021), Cydonia oblonga Mill. (Radović et al., 2016), Pyrus spp. (Motyleva et al., 2017), Aronia mitschurinii A.K. Skvortsov \& Maitul. (Grygorieva et al., 2018), Sambucus nigra L. (Horčinová et al., 2018, 2020).

We evaluated the variability of morphological characters of pollen grains (sporoform) and assessed their specific differences between selected genotypes of the species Malus domestica Borkh. Evaluation of the morphological features of pollen grains in seven randomly selected Slovakian genotypes is recorded in Table 1.

The pollen grains are medium-sized, as we can classify them in the 25-50 $\mu \mathrm{m}$ category. The mean size of the pollen grains ranges from $31.85 \mu \mathrm{m}$ to $42.85 \mu \mathrm{m}$ in length and from $21.23 \mu \mathrm{m}$ to $23.93 \mu \mathrm{m}$ in width. The smallest pollen grains from the tested genotypes were recorded at the $\mathrm{Md}-1 / 4$ genotype $(31.85 \mu \mathrm{m})$ and the largest at the $\mathrm{Md}-11 / 2$ genotype $(42.85 \mu \mathrm{m})$. The coefficient of variation indicates a certain degree of variability of the mentioned traits - the average length of the polar axis (6.05-10.68\%) and the equatorial axis (4.05-10.18\%). The genotype with the smallest pollen grains was characterized by the greatest variability in the mentioned traits. The shape index varied from 1.44 to 1.87 . The dimensions of the pollen grains of the species examined are presented in Table 1.

The outline of dried apple pollen grains is elliptical, and the polar view is circular. Based on the type and number of apertures pollen grains of Malus domestica are tricolpate (tricolporate - fresh pollen) with three germinal furrows without visible pores, each furrow extending almost the full length of the pollen grain. According to the location of apertures, pollens are zonocolpate. This means that the elongated apertures -

Table 1 Variability of the average length of the polar and equatorial axis of pollen grains of selected genotypes of the species Malus domestica Borkh.

\begin{tabular}{|c|c|c|c|c|c|c|c|c|c|}
\hline \multirow{2}{*}{ Genotypes } & \multicolumn{4}{|c|}{$\mathrm{P}-$ polar axis $(\mu \mathrm{m})$} & \multicolumn{4}{|c|}{$\mathrm{E}$ - equatorial axis $(\mu \mathrm{m})$} & \multirow[t]{2}{*}{ SI $(P / E)$} \\
\hline & $\min$ & $\max$ & $\mathbf{x}$ & V\% & $\min$ & $\max$ & $\mathbf{x}$ & V\% & \\
\hline Md-1/4 & 26.57 & 37.96 & 31.85 & 10.68 & 16.89 & 23.82 & 21.23 & 10.18 & 1.51 \\
\hline Md-1/8 & 29.69 & 42.82 & 33.64 & 8.30 & 19.35 & 27.91 & 23.54 & 9.65 & 1.44 \\
\hline Md-2/10 & 34.47 & 43.75 & 38.54 & 7.07 & 17.94 & 26.69 & 22.96 & 9.17 & 1.69 \\
\hline Md-5/12 & 32.78 & 40.01 & 36.14 & 6.05 & 22.90 & 26.02 & 23.87 & 4.05 & 1.52 \\
\hline Md-9/5 & 34.21 & 52.11 & 40.99 & 12.12 & 20.45 & 27.09 & 23.93 & 8.10 & 1.72 \\
\hline Md-11/2 & 36.13 & 46.86 & 42.85 & 6.30 & 19.69 & 29.93 & 23.09 & 9.08 & 1.87 \\
\hline Md-33/9 & 31.03 & 42.12 & 36.07 & 8.59 & 20.19 & 25.75 & 23.37 & 6.23 & 1.55 \\
\hline
\end{tabular}

Notes: min - minimal values; max - maximal values; $\mathrm{x}$ - arithmetic value; $\mathrm{V} \%$ - coefficient of variation; $\mathrm{SI}$ - shape index (P/E) 
Table 2 Literature data on pollen morphometric parameters in the Malus domestica Borkh.

\begin{tabular}{lccc}
\hline Characteristic & Value & Authors & Country \\
\hline & 32.17 & Pospiech et al., 2019 & Czech Republic \\
Polar axis $(\boldsymbol{\mu m})$ & $27.91-36.62$ & Motyleva et al., 2017 & Slovakia \\
& $46.0-48.3$ & Joneghani, 2008 & Iran \\
& $40.1-43.8$ & Currie et al., 1997 & Czech Republic \\
Equatorial axis $(\boldsymbol{\mu m})$ & 22.78 & Pospiech et al., 2019 & Slovakia \\
& $13.28-17.17$ & Motyleva et al., 2017 & Iran \\
SI - shape index & $18.8-21.2$ & Joneghani, 2008 Zealand & Czech Republic \\
& $20.9-23.2$ & Currie et al., 1997 & Iran \\
& 0.97 & Pospiech et al., 2019 & New Zealand \\
\hline
\end{tabular}

colps are distributed equidistantly - at the same distance on the surface of pollen grains with the centre in the equatorial plane. They are traditionally tapered towards poles. The place of narrowing of the ridges at the pole (apocolpium) has an average of 7.2-8.0 $\mu \mathrm{m}$. The mesocolpium or intercolpium is widest at the equator, i. e. at the same distance from both poles. The average width of the mesocolpium at the equator ranged from 15.0 to $25.2 \mu \mathrm{m}$. In the middle of the mesocolpium, we can observe the ridge of exina above the surface of the pollen grain.

The colour of pollen grains is also a taxonomic feature and tends to be different, mostly yellow in different shades. The colour of the pollen depends on the content of the type of plant dyes. The selected pollen grains were yellow with a shade of brown.

Based on the modern scanning electron microscope, we can compare Malus domestica pollen collected from various countries with our data (Table 2). Joneghami (2008) evaluated nineteen Malus species from botanical gardens and determined the mean size of the pollen grains ranges from $38.75 \mu \mathrm{m}$ (M. prattii) to $57.69 \mu \mathrm{m}$ (M. glaucescens) in length and from $19.15 \mu \mathrm{m}$ (M. kansuenses) to 28.74 (M. platycarpa) in width. The author described the surface of $M$. domestica pollen as rough, striate exine sculpture, long ridges, straight and parallel to the furrows, slightly curved at the ends; exine surface perforated and pits sparsely distributed. The spaces between the longitudinal ridges are wide for M. domestica (Joneghami, 2008).

Motyleva et al. (2017) studied pollen grains Malus domestica and Pyrus communis of Slovakia genotypes. Pollen of Malus domestica rocks is more elongated compared with the pollen of Pyrus communis (P/E is $14 \%$ more). The shape of the pollen grains is oblong- ellipsoidal. In terms of poles, the grain is round, the holes are long. A complex type of exine is characteristic of the studied species of Rosaceae.

Differentiation based on morphology has become difficult because of the increasing number of cultivars that have similar phenotypes (Whitmore, 1992). Methods of identification need to address also between sports arising from identical ancestors, because biochemical identification methods (DAN or isozyme "fingerprinting") have not differentiated sport derived from the same cultivar (Nybom, 1990; Marquard and Chan, 1995; Matsumoto et al., 1995; Sharon et al., 1995). Currie et al. (1997) characterized the apple sports of Red Delicious (Aversang and Ultrared), and Gala (Galalea and Splenola) genotypes from New Zealand according to quantitative data on pollen dimensions, ridge patterns and pore dimension with multivariate analyses (univariate analysis, multiple analysis of variance, canonical variate analysis, and discriminant analysis). Authors by these methods demonstrated differentiation between genetically and phenotypically similar apple genotypes and sports derived from the same cultivars.

Because pollen grain exine ornamentation is highly conserved and genetically stable (Sarwar and Takhashi, 2012), it has been often used to investigate plant origin, genetic evolution and systematic taxonomy (Sarwar et al., 2010; Sarwar and Takhashi, 2012; Qaiser et al., 2015). Zhang et al. (2017) evaluated exine ornamentation of 131 flowering crabapples - a group of small landscape trees or shrubs with reach germplasm of charming flowers, colourful fruits and many tree shapes. Authors examined parental and progeny population and described five types of flowering crabapple pollen exine ornamentation (a) Wholly 
Agrobiodivers Improv Nutr Health Life Qual, 5, 2021(2): 304-314

Table 3 Evidence of differences in the average length of the polar and equatorial axis of pollen grains between selected genotypes of the species Malus domestica Borkh.

\begin{tabular}{lccccccc}
\hline Genotypes & Md-1/4 & Md-1/8 & Md-2/10 & Md-5/12 & Md-9/5 & Md-11/2 & Md-33/9 \\
\hline \multirow{2}{*}{ Md-1/4 } & $\mathrm{P}$ & 0.0818 & $0.0000^{* *}$ & $0.0013^{* *}$ & $0.0000^{* *}$ & $0.0000^{* *}$ & $0.0004^{* *}$ \\
& $\mathrm{E}$ & $0.0005^{* *}$ & $0.0083^{* *}$ & $0.0017^{* *}$ & $0.0003^{* *}$ & $0.0045^{* *}$ & $0.0039^{* *}$ \\
Md-1/8 & 0.0818 & $\mathrm{P}$ & $0.0000^{* *}$ & $0.0326^{*}$ & $0.0000^{* *}$ & $0.0000^{* *}$ & $0.0146^{*}$ \\
& $0.0004^{* *}$ & $\mathrm{E}$ & 0.2579 & 0.6584 & 0.5314 & 0.3825 & 0.7698 \\
Md-2/10 & $0.0000^{* *}$ & $0.0000^{* *}$ & $\mathrm{P}$ & $0.0381^{*}$ & $0.0114^{*}$ & $0.0000^{* *}$ & $0.0121^{*}$ \\
& $0.0082^{* *}$ & 0.2579 & $\mathrm{E}$ & 0.2116 & 0.1106 & 0.7936 & 0.5099 \\
Md-5/12 & $0.0013^{* *}$ & $0.0326^{*}$ & $0.0381^{*}$ & $\mathrm{P}$ & $0.0002^{* *}$ & $0.0000^{* *}$ & 0.9572 \\
& $0.0017^{* *}$ & 0.6584 & 0.2116 & $\mathrm{E}$ & 0.9417 & 0.2866 & 0.5300 \\
Md-9/5 & $0.0000^{* *}$ & $0.0000^{* *}$ & $0.0114^{*}$ & $0.0002^{* *}$ & $\mathrm{P}$ & 0.0532 & $0.0001^{* *}$ \\
& $0.0003^{* *}$ & 0.5314 & 0.1106 & 0.9418 & $\mathrm{E}$ & 0.1690 & 0.4180 \\
Md-11/2 & $0.0000^{* *}$ & $0.0000^{* *}$ & $0.0000^{* *}$ & $0.0000^{* *}$ & 0.0532 & $\mathrm{P}$ & $0.0000^{* *}$ \\
& $0.1690^{* *}$ & 0.4180 & 0.1690 & 0.4180 & 0.1690 & $\mathrm{E}$ & 0.6592 \\
Md-33/9 & $0.0004^{* *}$ & $0.0146^{*}$ & $0.0121^{*}$ & 0.9572 & $0.0002^{*}$ & $0.0000^{*}$ & $\mathrm{P}$ \\
\hline
\end{tabular}

Notes: ${ }^{*}-\mathrm{p}<0.05$; $^{*}-\mathrm{p}<0.01 ; \mathrm{P}-$ polar axis; $\mathrm{E}-$ equatorial axis

Regular Single-pattern Type (e.g. M. robusta), (b) Wholly Regular Multi-pattern Type (e.g. M. halliana cultivar Pink Double), (c) Partially Regular Singlepattern Type (e.g. M. cultivar Red Baron), (d) Partially Regular Multi-pattern Type (e.g. M. cultivar Everest), (e) Irregular Type (e.g. M. cultivar Velvet Pillar).

Table 3 illustrates the results of the significance of the differences observed in the tested morphological traits of pollen grains between specific genotypes. Statistical analysis (ANOVA) confirmed the significance of the difference (at a significance level $p<0.05$ ) in the average length of the polar axis $(x=38.54)$ of the $\mathrm{Md}-2 / 10$ genotype from the other genotypes tested. We noted that a close relationship (alpha 0.05) between $\mathrm{Md}-1 / 4$ and $\mathrm{Md}-1 / 8$ genotype pairs and between Md-11/2, Md-33/9 and Md-5/12. In the case of the equatorial axis, the genotype Md-1/4 ( $x=21.23)$ differed significantly from other genotypes, which did not differ significantly.

Data could be considered that hierarchical cluster analysis separates pollen selections into three closely related groups - main clusters. Other authors have also used cluster analyses to evaluate the morphological data of pollen, including pollen characteristics enabling a better understanding of taxonomic classification, the genus or subgenus relationships or phylogenetic lineages (Grygorieva et al., 2015, 2016, 2018; Horčinová et al., 2018, 2020, 2021; Baldemir et al., 2018; Soares et al., 2018).
The results of the cluster analysis simply illustrate groupings of genotypes with similar morphological characters.

Based on cluster analysis, the relationships of the tested genotypes according to morphological features are graphically displayed on a dendrogram (Figure 1).

The dendrogram demonstrates that genotypes represent a more heterogeneous group. Based on the evaluated morphological features, two genotypes Md-1/4 and Md-11/2 are the most separated from the set of genotypes (Figure 2), different from the other five, which form the second group of mutually closer genotypes.

Sculpture (structure) of exina, e.i. the outer sporopollenin layer of sporoderma (pollen grain membranes) is an important morphological feature that is used to identify species in recent and fossil pollen, as it is specific to the species (Benčat' et al., 1988; Ostrolucká, and Križo, 1989; Bolvanský and Ostrolucká, 1998). Exine sculpturing is not homogenous. Specific for the sculpture of the surface of the exine pollen of genotypes of the species Malus domestica Borkh. there are different thicknesses, densities, different arrangements, even plastically elevated structural elements in different directions looking like freestanding elements (baculum), which would correspond to the type of baculate sculpture. Between the scattered baculum elements, perforations are visible in places, mostly in the shape of round holes or even directly on their surface (Figure 3b/6B). According to literary data 


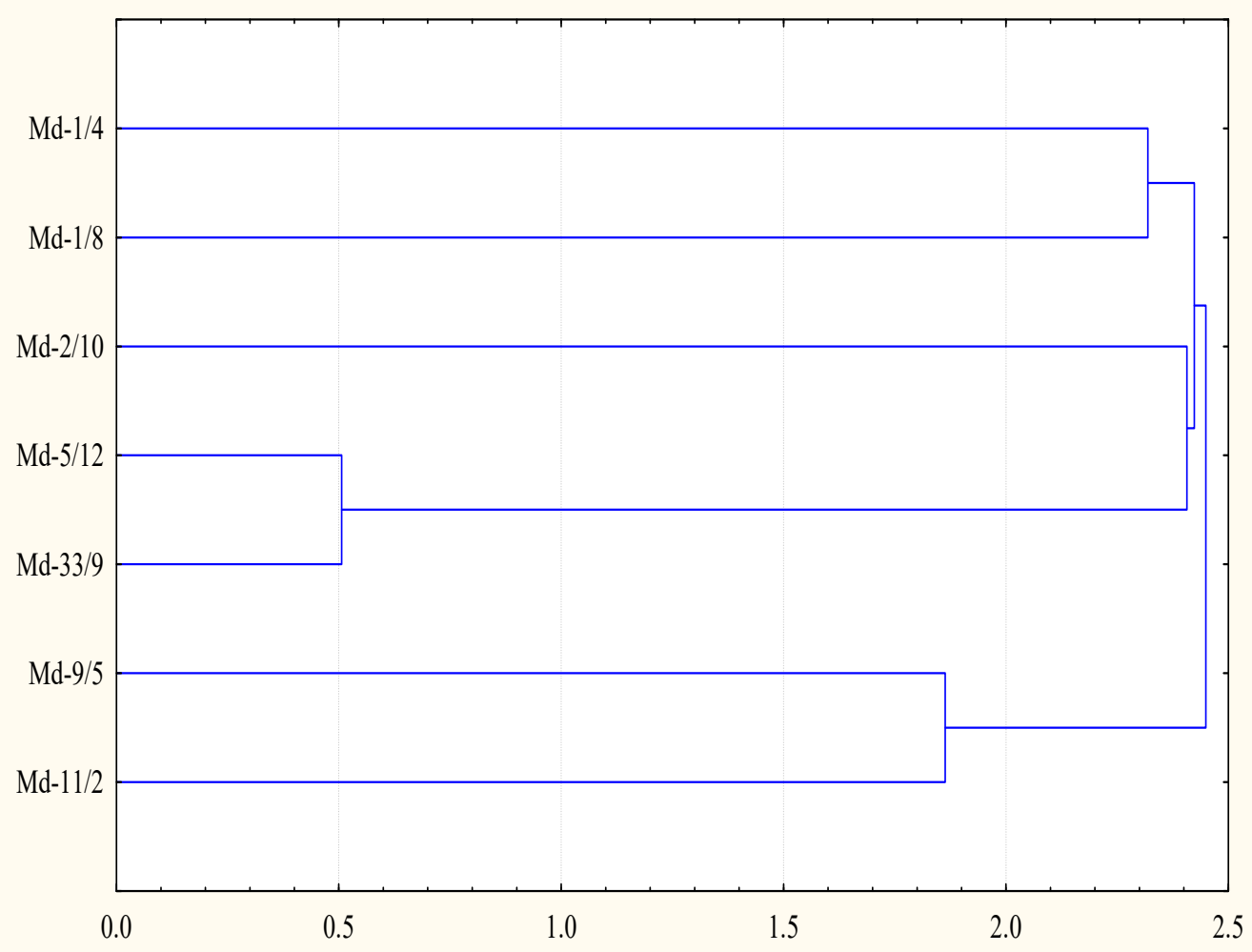

Figure 1 Cluster dendrogram of the relationship of evaluated genotypes of Malus domestica Borkh. according to morphometric features of pollen grains

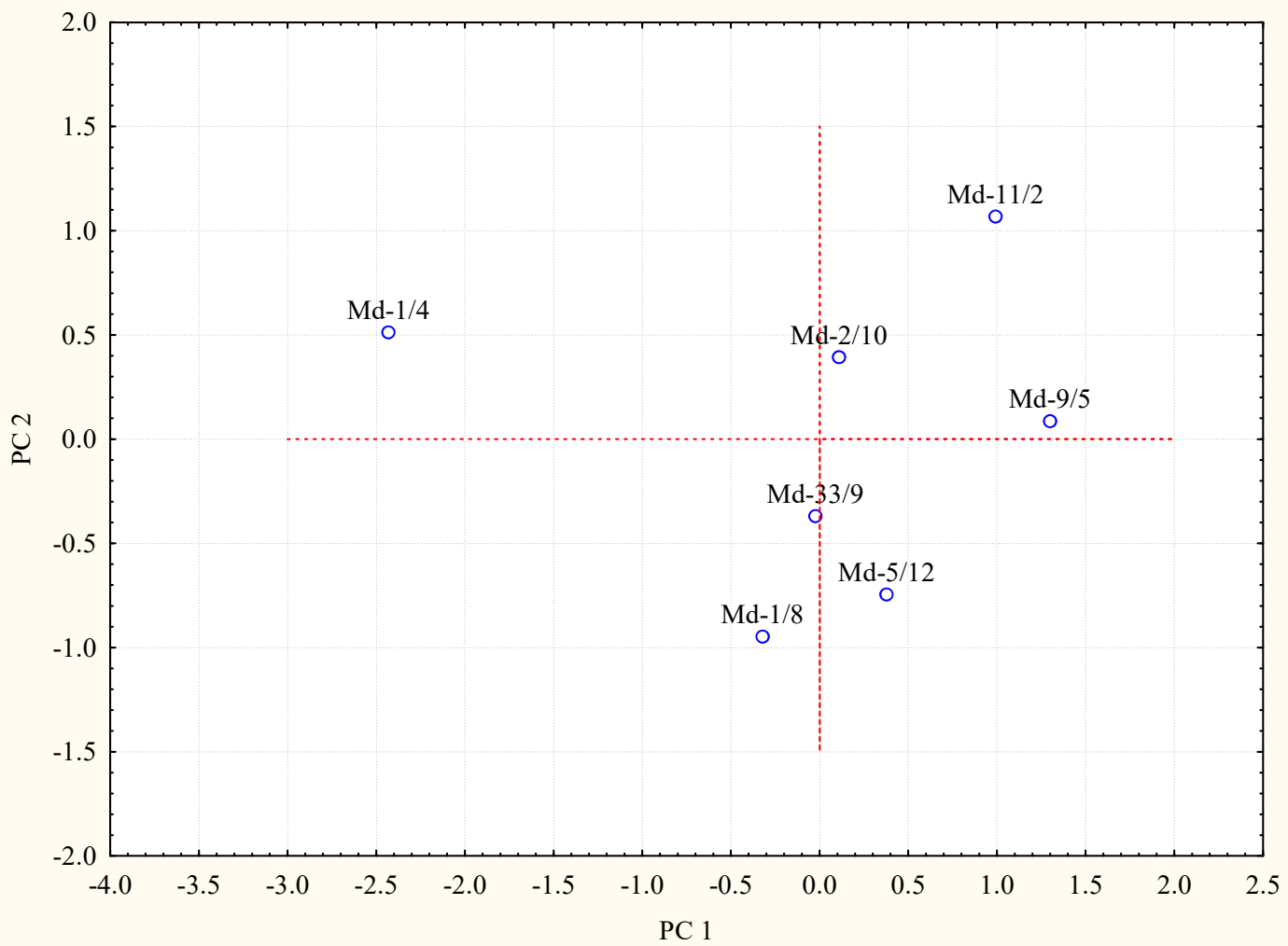

Figure 2 Biplot based on principal components analysis (PCA) for pollen quantitative and qualitative characteristics parameters of Malus domestica Borkh. 7 genotypes 



Figure 3a Pollen grain of the species Malus domestica Borkh.

1 - MD-1/4; 2 - MD-1/8; 3 - MD-2/10; 4 - MD-5/12; 5 - MD-9/5; 6 - MD-11/2; 7 - MD-33/9; 1A, 4A, 5A, 6A, 7A - pollen grain in equatorial position with one aperture; $2 \mathrm{~A}, 3 \mathrm{~A}$ - pollen grain in equatorial position with two apertures; $\mathrm{A}$ figures (Scale bar $=1 \mu \mathrm{m} \times 3000$ ), B figures - detail of the sculpture of the exina surface in the place of the mesocolpium (Scale bar $=1 \mu \mathrm{m} \times 10000$ )

Photo by Svetlana Motyleva, 2011 

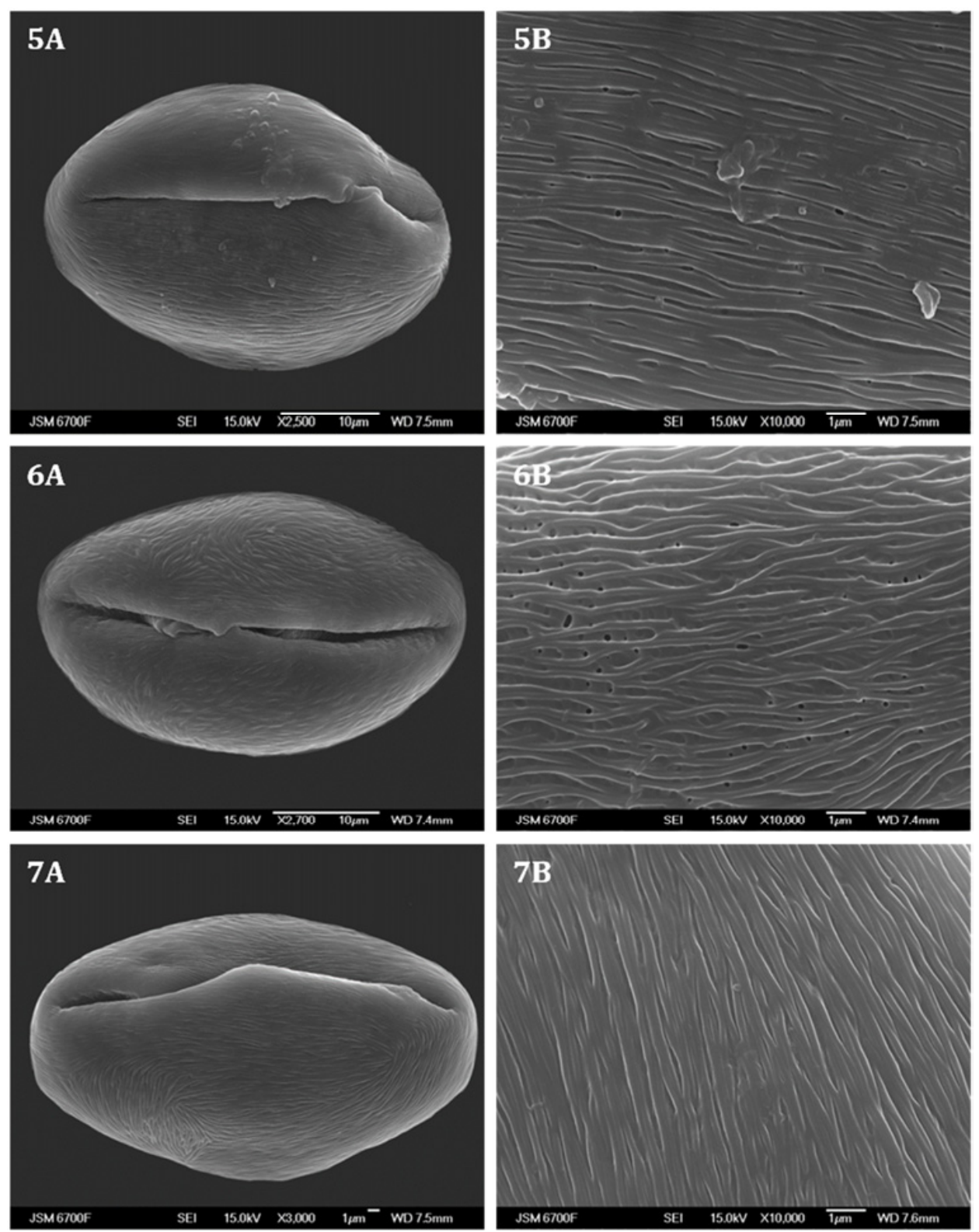

Figure 3b Pollen grain of the species Malus domestica Borkh.

1 - MD-1/4; 2 - MD-1/8; 3 - MD-2/10; 4 - MD-5/12; 5 - MD-9/5; 6 - MD-11/2; 7 - MD-33/9; 1A, 4A, 5A, 6A, 7A - pollen grain in equatorial position with one aperture; $2 \mathrm{~A}, 3 \mathrm{~A}$ - pollen grain in equatorial position with two apertures; $\mathrm{A}$ figures (Scale bar $=1 \mu \mathrm{m} \times 3000)$, B figures - detail of the sculpture of the exina surface in the place of the mesocolpium (Scale bar $=1 \mu \mathrm{m} \times 10000$ )

Photo by Svetlana Motyleva, 2011

(Currie et al., 1997; Joneghani, 2008), exine sculpturing is variable but mostly striate, species may differ in the degree of density of ridges and their orientation. The ridges may be widely spaced resulting in reticuloid patterns, or they may be densely packed with obscured perforations. Ridges also vary from long and parallel to short and irregular in Malus L. species. The detail of the microstructure of exine pollen in individual genotypes, even with some differences, is documented in Figure 3a, b.
One criterion for identifying genotype differentiation was the perforation of the surface of the pollen grain exine, its presence (Figure $3 a / 2 B, 5 B, 6 B$ ) or absence (Figure 3a/1B, 3B, 4B, 7B) and the number of perforations per unit area $\left(\mathrm{mm}^{2}\right)$ : less than 400 thousand $/ \mathrm{mm}^{2}$ (Figure 3a/2B, $5 \mathrm{~B}$ ) and more than 400 thousand $/ \mathrm{mm}^{2}$ (Figure $3 \mathrm{~b} / 6 \mathrm{~B}$ ). Another criterion appears to be the character of the sculptural elements of the exina of pollen grains and especially the presence of bonding rod-shaped or striped elements (Figure $3 \mathrm{ab} / 3 \mathrm{~B}, 5 \mathrm{~B}, 7 \mathrm{~B}$ ) or their absence (Figure 3ab/1B, 


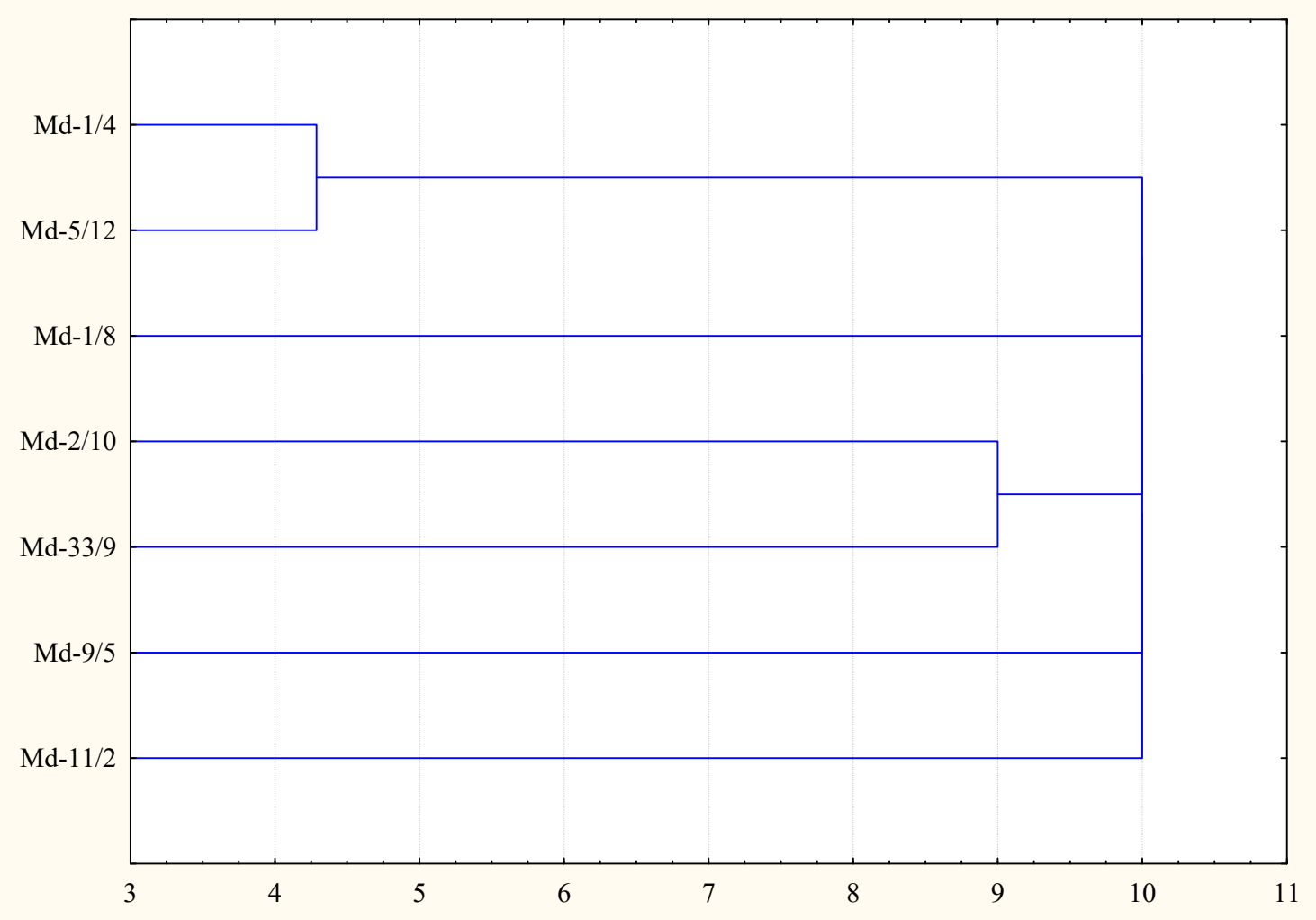

Figure 4 Cluster dendrogram of morphometric parameters pollen of Malus domestica Borkh. genotypes

2B, 4B, 5B), and their tortuousness (Figure 3ab/6B) or straightness (other figures). Based on the above mentioned, we classified the genotypes according to dendrogram (Figure 4):

Type I (genotype $\mathrm{Md}-11 / 2$ ) - the presence of irregular striped sculptural elements, unconnected and the presence of perforations.

Type II (Md-9/5) - the presence of straight striped sculptural elements, connected and the presence of perforations.

Type III (Md-2/10 and Md-33/9) - the presence of straight striped sculptural elements, connected and absence of perforations.

Type IV (Md-1/8) - the presence of straight striped sculptural elements, unconnected and presence of perforations.

Type V (Md-1/4 and Md-5/12) - the presence of straight striped sculptural elements, connected and the absence of perforations.

\section{Conclusions}

The studying of the Malus domestica pollen via scanning electron microscope allowed us to determine the most important parameters which can be used to identify the representatives of species. The detailed pollen morphological and micro-sculptural characteristics were investigated, described and analysed by using hierarchical cluster analyses dendrograms and BiPlot (PC1 and PC2). The main parameters such as the form (the pollen grains elongation, $\mathrm{P} / \mathrm{E}$ ratio) are specific for different Malus species. Results from our analyses showed differences among Malus domestica genotypes. Some of these pollen morphological parameters can be used for identification and comparison with the following analyses of Malus species.

\section{Conflict of interests}

The authors declare that they have no competing interests.

\section{Ethical statement}

This article complies with all ethical standards.

\section{Funding}

Co-author is grateful to SAIA and Visegrad Fund for the scholarship for the research during which the presented knowledge was obtained.

\section{Acknowledgements}

The publication was prepared with the active participation of researchersinvolved inthe International 
Network AgroBioNet of the Institutions and researchers for the realization of research, education, and development program «Agrobiodiversity for improving nutrition, health and life quality» and within the project ITEBIO - ITMS 26220220115.

\section{References}

Arzani, K., Nejatian, M. A., \& Karimzadeh, G. (2005). Apricot (Prunus armeniaca) pollen morphological characterisation through scanning electron microscopy, using multivariate analysis. New Zealand Journal of Crop and Horticultural Science, 33, 381-388.

Auer, W. (2021). Malus domestica. In: PalDat - A palynological database.

https://www.paldat.org/pub/Malus domestica/306280 (accessed 2021-11-02).

Baldemir, A., Alan, S., Șahin, A.A., Paksoy, M. Y., \& Pinar, N. M. (2018). Pollen morphology of Scaligeria DC. (Apiaceae) in Turkey. Turkish Journal of Botany, 42, 462-477. https://doi.org/10.3906/bot-1705-43

Benčat', F., Ostrolucká, M. G., \& Caňo, F. (1988). Morphology of pollen grains of some woody species introduced from China into the conditions of Arborétum Mlyňany. Folia Dendrologica, 15, 17-65.

Blackmore, S., Wortley, A. H., Skvarla, J. J., \& Rowley, J. R. (2007). Pollen wall development in flowering plants. New Phytologist, 174, 483-498.

Bolvanský, M., \& Ostrolucká, M. G. (1998). Uchovanie genofondu rastlín pelom [Preservation of plant gene pool by pollen]. Edícia: Ochrana biodiverzity. Nitra: SPU. ISBN 80-7137-574-8 [In Slovak].

Currie, A. J., Noiton, D. A., Lawes, G. S., \& Bailey, D. (1997). Preliminary results of differentiating apple sports by pollen ultrastructure. Euphytica, 98(3), 155-161.

Dogan, C., \& Baysal, E. (2019). Pollen morphology of the coastal species of Turkish Limonium (Plumbaginaceae). Phytotaxa, 388(3), 212-228. https://doi.org/10.11646/phytotaxa.388.3.1

Elysiane, M., Claudia, B., Claudia, M., \& Vania, E. (2018). Pollen morphology of Mourera (Podostemaceae). Palynology, 42(4), 553-559.

https://doi.org/10.1080/01916122.2017.1403390

Erdtman, G. (1969). Handbook of Palynology: An Introduction to the Study of Pollen Grains and Spores. Verlag Munksgaard: Copenhagen.

Fogle, W. H. (1977a). Identification of clones within four tree fruit species by pollen exine patterns. Journal of the American Society for Horticultural Science, 102(5), 552-560.

Fogle, W. H. (1977b). Identification of tree fruit species by pollen ultrastructure. Journal of the American Society for Horticultural Science, 102(5), 548-551.

Grygorieva, O., Vičan, J., Schubertová, Z., Šimková, J., Adamchuk, L., \& Brindza, J. (2016). Morphological characteristics of pollen grains and bee pollen of sweet chestnut (Castanea sativa Mill.). Agrobiodiversity for Improving Nutrition, Health, and Quality of Life, 107-114.

Grygorieva, O., Brindza, J., Ostrolucká, M. G., Ostrovský, R., Klymenko, S., Nôžková J., \& Tóth, D. (2010). Pollen characteristics in some persimmon species (Diospyros spp.). Agriculture, 56(4), 121-130. https://www. agriculture.sk/fileadmin/agriculture/files/2010/ Issue 4/BrindzaXX.pdf

Grygorieva, O., Klymenko, S., Vinogradova, Y., Motyleva, S., Gurnenko, I., Piórecki, N., \& Brindza, J. (2018). Study of morphological characteristics of pollen grains of Aronia mitschurinii A.K. Skvortsov \& Maitul. Agrobiodiversity for Improving Nutrition, Health and Life Quality, 2, 49-56. https://doi.org/10.15414/ agrobiodiversity.2018.2585-8246.049-056

Grygorieva, O., Motuleva, S., Nikolaieva, N., Klymenko, S., Schubertová, Z., \& Brindza, J. (2017). Pollen grain morphological characteristics of American Persimmon (Diospyros virginiana L.). Agrobiodiversity for Improving Nutrition, Health and Life Quality, 1, 151-158. $\quad$ http://dx.doi.org/10.15414/ agrobiodiversity.2017.2585-8246.151-158

Grygorieva, O., Nikolaieva, N., Brindza, J., \& Klymenko, S. (2015). Pollen and bee pollen features of sweet chestnut (Castanea sativa Mill.). Scientific Bulletin of the National University of Life and Environmental Sciences of Ukraine. Series: Technology of production and processing of livestock products [online], 223, 35-40

Halbritter, H.,Ulrich, S., Grimsson, F., Weber, M.,Zetter, R., Hesse, M., Buchner, R., Svojtka, M., \& Frosch-Radivo, A. (2018). Palynology: History and Systematic Aspects. Illustrated Pollen Terminology. Springer: Cham. https://link. springer.com/chapter/10.1007/978-3-319-71365-6 1

He, C. X., \& Hsu, P. S. (1991). Pollen morphology of the genus Malus and its taxonomic and evolutionary significance. Acta Phytotaxonomica Sinica, 29, 445-451.

Hebda, R. J., Chinnappa, C. C., \& Smith, B. M. (1988). Pollen morphology of the Rosaceae of western Canada. II Dryas, Fragaria, Holodiscus. Canadian Journal of Botany, 68, 595-612.

Horčinová Sedláčková, V., Grygorieva, O., \& Gurnenko, I. (2021). Study of morphological characters of pollen grains Sweet Chestnut (Castanea sativa Mill.) by scanning electron microscopy. Agrobiodiversity for Improving Nutrition, Health and Life Quality, 5(1), 116-125. https://doi.org/10.15414/ainhlq.2021.0012

Horčinová Sedláčková, V., Grygorieva, O., Gurnenko, I., \& Brindza, J. (2018). Study of morphological characteristics of pollen grains of Sambucus nigra L. Agrobiodiversity for Improving Nutrition, Health and Life Quality, 2, 277-284. https://doi.org/10.15414/ agrobiodiversity.2018.2585-8246.277-284

Horčinová Sedláčková, V., Grygorieva, O., Gurnenko, I., \& Vergun, O. 2020. Diversity of Sambucus nigra pollen within Slovakia in selected morphological characters by SEM study. Biosystems Diversity, 28(4), 399-404. https://doi.org/10.15421/012051 
Joneghani, N. V.(2008). Pollen morphology of the genus Malus (Rosaceae). Iranian Journal of Science \& Technology, Transaction A, 32(A2), 89-97.

Katifori, E., Alben, S., Cerda, E., Nelson, D. R. \& Dumais, J. (2010). Foldable structures and the natural design of pollen grains. P. Nas. US, 107, 7635-7639.

Marcucci, M. C., Sansavini, S., Ciampolini, F., \& Cresti, M. (1984). Distinguishing apple clones and cultivars by surface morphology and pollen physiology. Journal of the American Society for Horticultural Science, 109(1), 10-19.

Marquard, R. D., \& C. R. Chan (1995). Identifying crabapple cultivars by isozymes. Journal of the American Society for Horticultural Science, 120(5), 706-709.

Martens, J., \& Fretz, T. A. (1980). Identification of eight crabapples by pollen surface sculpture. Journal of the American Society for Horticultural Science, 105(2), 257-263.

Matsumoto, S., Hoshi, N., Tsuchiya, T., Soejima, J., Komori S., \& Ejiri, S. (1995). S-RNase like genomic sequences in apple for DNA fingerprinting. Acta Horticulturae, 392, 265-274.

Mert, C. (2009). Pollen morphology and anatomy of Cornelian Cherry (Cornus mas L.) cultivars. HortScience, 44(2), 519-522. http://hortsci.ashspublications.org/ content/44/2/519.full.pdf

Miaja, M. L., Radicati, L., Porporato, M., Caramiello, R., Fossa, V., \& Vallania, R. (2000). Morpho-physiological observations on pollen of sour cherry (Prunus cerasus L.). Acta Horticulturae, 514, 311-318.

Motyleva, S. M., Brindza, J., Šimková, J., \& Horčinová Sedláčková, V. (2018). Comparative study of morphometric characteristics and mineral composition of pollen Malus domestica Borkh. Agrobiodiversity for Improving Nutrition, Health and Life Quality, 2, 285-291. https://doi.org/10.15414/ agrobiodiversity.2018.2585-8246.285-29

Motyleva, S., Brindza, J., \& Kulikov, I. (2017). The morphology of pollen grains of the some species of Rosaceae Juss. family. Agrobiodiversity for Improving Nutrition, Health and Life Quality, 1, 338-341. http://dx.doi. org/10.15414/agrobiodiversity.2017.2585-8246.338-3

Nikolaieva, N. V., Grygorieva, O. V., Brindza, J., Garkava, K. G., \& Klymenko, S. V. (2014). Morphological features of pollen Corylus avellana L. and Castanea sativa Mill. as indicator of environmental changes. Plodovodstvo i yagodovodstvo Rossii: sbornik nauchnyih rabot, 40(1), 232-238.

Nybom, H. (1990). DNA fingerprints in sports of 'Red Delicious' apples. Hort Science, 12, 1641-1642.

Ostrolucká, M. G., \& Križo M. (1989). Biológia samčích reprodukčných orgánov druhov rodu Quercus L. [Biology of male reproduction organs in species of the genus Quercus L.]. Acta Dendrobiologica. Bratislava: Veda, SAV. ISBN 80-224-0133-1 [In Slovak].
Pospiech, M., Javůrková, Z., Tremlová, B., \& Běhalová, H. (2019). Characterization of fruit trees pollen. Potravinarstvo Slovak Journal of Food Sciences, 13(1), 634-643. https://doi.org/10.5219/1096

Qaiser, M., Perveen, A. \& Sarwar, G. R. (2015). Pollen morphology of the family Crassulaceae from Pakistan and Kashmir and its taxonomic implications. Pakistan Journal of Botany, 47, 1481-1493.

Radović, A., Nikolić, D., Milatović, D., Đurović, D., \& Trajković, J. (2016). Investigation of pollen morphological characteristics in some quince (Cydonia oblonga Mill.) cultivars. Turkish Journal of Agriculture and Forestry, 40, 441-449. http://dx.doi.org/10.3906/tar-1511-76

Sarwar, A. K. M. G., \& Takahashi, H. (2012). Pollen morphology of Kalmia L. (Phyllodoceae, Ericaceae) and its taxonomic significance. Bangladesh Journal of Plant Taxonomy, 19, 123-133.

Sarwar, A. K. M. G., Hoshino, Y., \& Araki, H. (2010). Pollen morphology and infrageneric classification of Alstroemeria L. (Alstroemeriaceae). Grana, 49, 227-242.

Sharon, D., Adato, A., Mhameed, S., Lavi, U., Hillel, J., Gomolka, M., Epplen, C., \& Epplen, J. T. (1995). DNA fingerprints in plants using simple-sequence repeat and minisatellite probes. Hort Science, 30(1), 109-112.

Smitha, K., Paton, A., \& Sunojkumar, P. (2018). Reestablishment of Plectranthus bishopianus (Lamiaceae) based on morphological and micromorphological data. Plant Systematics and Evolution, 304(7), 807-816. https://doi.org/10.1007/s00606-018-1511-6

Soares, R. L., Jesus, O. N., Souza, E. H., Rossi, M. L., \& Oliveira, E. J. (2018). Comparative pollen morphological analysis in the subgenera Passiflora and Decaloba. Annals of the Brazilian Academy of Sciences, 90(2), 2381-2396. https://doi.org/10.1590/0001-3765201720170248

Stehlíková, B. (1998). Základy bioštatistiky [Fundamentals of biostatistics]. Učebné texty pre dištančné štúdium. Nitra : Ochrana biodiverzity. [In Slovak].

Walker, J. W. (1974). Evolution of exine structure in the pollen of primitive angiosperms. American Journal of Botany, 61, 891-902.

Zhang, W.-X., Zhao, M.-M., Fan, J.-J., Zhou, T., Chen, Y.-X., \& Cao, F.-L. (2017). Study on relationship between pollen exine ornamentation pattern and germplasm evolution in flowering crabapple. Scientific Reports, 7(39759), 1-11. https://doi.org/10.1038/srep39759 